Social Work \& Education

๑) SW\&E, 2019

Удк 316.6

DOI: $10.25128 / 2520-6230.19 .3 .4$

\section{Олена Маляр,}

кандидат психологічних наук, старший викладач

кафедри психолого-педагогічної освіти та сочіальних наук

КВНЗ «Вінницька академія неперервної освіти»

м. Вінниця, Украӥна

malayryk@gmail.com

Article history:

Received: Febuary 23, 2019

1st Revision: March 22, 2019

Accepted: September 30, 2019
Маляр, О. (2019). Соціально-психологічний тренінг формування дитячо-батьківських стосунків та емоційної взаємодії вчителя 3 дитиною у контексті роботи соціального працівника. Social Work and Education. Vol.6, No. 3. Ternopil-Aberdeen, 2019. pp. 259-268. DOI: $10.25128 / 2520-6230.19 .3 .4$

\section{СОЦАЛЬНО-ПСИХОЛОГІЧНИЙ} ТРЕНІНГ ФОРМУВАННЯ ДИТЯЧОБАТЬКІВСЬКИХ СТОСУНКІВ ТА ЕМОЦЙНОЇ ВЗАСМОДЇ̈ ВЧИТЕЛЯ 3 ДИТИНОЮ У КОНТЕКСТІ
РОБОТИ СОЦІАЛЬНОГО
ПРАЦІВНИКА

\begin{abstract}
АНОТАЦІЯ. У статті розглянуто соціальнопсихологічний тренінги як один із найбільш ефективних напрямків роботи соціального працівника 3 дітьми та сімями. Даний тренінг сприяє вирішенню широкого кола завдань, передусім пов'язаних зі спілкуванням в родині, спрямованість на корекцію і розвиток системи стосунків особистості - компетентність у спілкуванні з дитиною. У контексті дослідження розкрито суть поняття соціальнопсихологічного тренінгу у роботі соціального працівника.

Описано тренінг для батьків i вчителів, щодо розуміння розвитку емоційної сфери дитини та сприянню без конфліктного спілкуванню. Презентовано етапи підготовки батьків та вчителів у прийняті участі у соціально-психологічному тренінгу, що забезпечують позитивне сприйняття тренінгових занять 3 ними. Описано структура соціально-психологічного тренінгу 3 формування позитивних дитячо-батьківських стосунків та емоційна взаємодія вчителя 3 дитиною молодшого шкільного віку, який складається з п'яти занять.

Зроблено висновок, що використання соціальнопсихологічного тренінгу 3 сім'єю та педагогічними працівниками у роботі соціального працівника забезпечує позитивне сприйняття батьками та вчителями особливостей соціального та психологічного розвитку дитини та формування у дорослих толерантного спілкування з навколишніми.

Ключові слова: тренінг; соціально-психологічний тренінг; соціальний працівник; батьки; вчителі; молодший школяр.
\end{abstract}




\section{Вступ}

Соціальна робота як практична діяльність особистості розвивається i вдосконалюється. Одним 3 головних компонентів діяльності соціального працівника є робота з сім'єю та дорослими, яка здійснюється через соціальну профілактику, соціальний патронаж, соціальну реабілітацію та надання соціально-психологічної, психолого-педагогічної, соціально-медичної, соціальноправової, консультативної, психотерапевтичної допомоги та підтримки взаємостосунках батьків 3 дітьми у тісній співпраці з педагогами системи освіти.

Загалом порушень у сфері дитячо-батьківських стосунків та емоційній взаємодії вчителя з дитиною, зумовлюють відсутності відповідальності членів сім'ї за свою поведінку, соціальну незахищеність дітей і зниження їх соціального статусу у освітніх закладах. Тому не можна уявити собі практичної діяльності соціального працівника без різних видів групової роботи з сім'ями та дорослими. Однією із форм такої роботи є соціально-психологічний тренінг, який забезпечує формування навиків доброзичливого ставлення дорослого до дитини $\mathrm{i}$ навколишніх. Соціально-психологічний тренінг - найперспективніший метод усвідомлення дорослим конструктивних взаємовідносин з дитиною, які пов'язані з іiі успішною соціальною адаптацією. Рушійні сили навчання на такому тренінгу - це власний досвід учасників; соціальне переконання; зворотній психологічний зв'язок; отримання порівняльної інформації зі спостережень за іншими. Слід зауважити, що соціально-психологічний тренінг є одним із важливих компонентів у роботі соціального працівника, адже його головним обов'язком являється ефективне спілкування з людьми та підтримка позитивної взаємодії дорослих 3 дітьми.

\section{Аналіз останніх публікацій}

Тренінг являє собою динамічну форму навчання, в ході якої відбувається активне засвоєння знань, умінь та навичок, яке відповідає умовам сучасного життя. Термін "тренінг" (від англ. train, training) має багато значень. Це навчання, виховання, тренування, дресирування. Тренінг - це сукупність прийомів і способів, спрямованих на розвиток у людини тих або інших навичок і умінь (Шапар В.Б., 2004).

Теоретичні й методичні основи соціально-психологічного тренінгу як методу описані в працях В.Ю. Большакова, І.В. Вачкова, Д.У. Джонсона, О.В. Свтіхова, Ю.М. Ємельянова, В.П. Захарова, Н.В. Клюєвої. В. М. Федорчук наголошують, що особливістю соціально-психологічного тренінгу є спосіб активного навчання за допомогою набуття життєвого досвіду, що відбувається у спеціально створених умовах завдяки моделюванню життєвих ситуацій (Федорчук В.М., 2014). Як зазначає Г.А. Ковальов, соціально-психологічний тренінг відноситься 
до методів активного соціально-психологічного навчання як комплексного соціально дидактичного напряму (Ковалев Г. А., 1998).

Б.Д. Паригін описує його як активне групове навчання навикам спілкування в житті і суспільстві, сім'ї: від навчання професійно корисним навикам до адаптації до нової соціальної ролі 3 відповідною корекцією «Я-концепції» і самооцінки (Практикум по СПТ, 2000). Соціально-психологічний тренінг визначається як область практичної психології, зорієнтована на використання активних методів групової соціально-психологічної роботи з метою розвитку компетентності у спілкуванні, що є основою у роботі соціального працівника. Ю.І. Жуков, П.В. Растянніков визначають компетентність у спілкуванні як здатність встановлювати і підтримувати контакти, не тільки з навколишніми, а й із родичами (Жуков Ю. М., 1990). До компетентності входить вся сукупність знань і умінь, що забезпечують ефективне протікання спілкування 3 оточуючими та 3 сім'єю, особливо, при взаємодії дорослого з соціальним працівником.

Метою статті $є$ здійснити теоретичний аналіз поняття соціальнопсихологічного тренінгу та презентувати розроблений тренінг, який вдосконалює навички розуміння в дорослих особливостей дитячо-батьківських стосунків та емоційної взаємодії вчителя з дітьми в контексті роботи соціального працівника.

Завдання статті передбачають: розкрити суть поняття соціальнопсихологічного тренінгу у роботі соціального працівника; описати розроблений тренінг для батьків та вчителів, щодо розуміння розвитку емоційної сфери дитини та сприянню без конфліктного спілкуванню.

\section{Методологія дослідження}

Для досягнення мети було використано наступні методи: аналіз, узагальнення наукової літератури з питання використання соціально-психологічного тренінгу соціальним працівником у роботі з сім'єю та педагогічними працівниками. Соціально-психологічний тренінг проводився 3 сім'ями, які мають різний соціальний статусу, освіту та вчителями освітніх закладів у Вінницькій області. Опис тренінгу який сприяє формуванню позитивних, гармонійних взаємостосунків батьків, педагогів з дітьми та розумінню особливостей розвитку дитини для подальшої успішної соціальної адаптації підростаючої особистості.

\section{Основна частина}

Соціально-психологічний тренінг формує у людини якості (толерантності та співчуття) і навчає та допомагає ефективно взаємодіяти з оточуючими. Е. Мастей підкреслює значення досвіду тісної прив'язаності у розвитку життєздатності людини й іiі здатності у подальшому забезпечувати стабільні доброзичливі стосунки з членами своєї сім'ї і зі своїм соціальним оточенням, а в більш ранніх 
роботах автор розвиває ідею про те, що важливою складовою розвитку життєздатності дитини є батьківська ефективність та іiі взаємодія 3 педагогом (Masten A.S., 2007; Masten A.S., 2001). Також, адекватна взаємодія з батьками та вчителями дозволяє дітям вдосконалювати соціальні навички, які потім стають дуже корисними при взаємодії з навколишніми. (Шаргородська С., 2007).

На етапі підготовки батьків та вчителів до участі у нашому соціальнопсихологічному тренінгу використовували консультування батьків та вчителів, які містять у собі кілька етапів, для позитивного сприйняття тренінгових занять. Завдання першого етапу - створити довірчі, відверті відносини 3 батьками та вчителями, особливо з тими, хто заперечує можливість і необхідність співробітництва. В даному випадку можна застосовувати таку форму індивідуального консультування, як бесіда. Слід пам'ятати, що в процесі бесіди потрібно виключати пряму або непряму критику дій дорослих, сумніви в їхній психолого-педагогічній та соціальній компетентності. Зауважимо, що це доречно лише в тактовній формі після аналізу сукупності відомостей про дитину, у тому числі результатів іiі обстеження. При перших же зустрічах будь-який натяк на несхвалення дій батьків та вчителів може спровокувати в них сильні захисні реакції і закриє шлях для відвертого обговорення всіх проблем, що наявні в дитини.

Другий етап проводився за підсумками всебічного обстеження дитини. Він має також кілька цілей: детальний аналіз загального стану психічного розвитку i особистісних особливостей дитини, а також характеру, ступеня i причин виявлених труднощів, обережно обговорювалися перспективи розвитку та навчання дитини, а увага батьків зосереджувалася на їхніх можливостях надання допомоги дитині; роз'яснення конкретних заходів цієї допомоги із урахуванням специфіки розвитку дитини, пояснення необхідності участі батьків, особливо, вчителів у загальній системі соціальної та психолого-педагогічної підтримки; обговорення проблем дорослих, їхнє відношення до труднощів, наявних у поведінці, спілкуванні або навчанні дитини.

На третьому етапі проводиться корекційна робота, змінювалися завдання консультування, які припускали формування в батьків та вчителів педагогічної компетентності через розширення кола їхніх соціальних і психолого-педагогічних знань і уявлень; залучення до конкретних корекційних заходів з їхньою дитиною як активних учасників цього процесу (Туріщева Л.В., 2007).

Таким чином, у взаємовідносинах батьків та вчителів 3 дітьми, необхідне глибоке розуміння внутрішнього світу дітей, урахування соціальних та психологічних особливостей, їхньої емоційно-вольової сфери, уміння передбачити, яка міра впливу може бути успішною для розвитку особистості дитини, тобто використання індивідуального підходу. Все це ми намагалися розкрити у нашому соціально-психологічному тренінгу для батьків та вчителів: 
«Формування позитивних дитячо-батьківських стосунків та емоційна взаємодія вчителя $з$ дитиною молодшого шкільного віку».

Метою соціально-психологічного тренінгу було поглибити знання батьків та вчителів з проблеми розвитку емоційної сфери молодших школярів; підвищити соціально-психологічну компетентність дорослих у питаннях дитячо батьківських стосунків, емоційної взаємодії вчителя з дитиною.

Даний тренінг передбачає ознайомити батьків та вчителів з особливостями розвитку емоційно-вольової сфери дітей молодшого шкільного віку; формуванням позитивних, гармонійних взаємостосунків батьків, педагогів 3 дітьми; розумінням складного емоційного світу дитини та недоцільністю оцінювального ставлення до різних дитячих емоційних реакцій; уявленням про особливості емоційних взаємин дорослих 3 дітьми; навиками рефлексивного аналізу емоційних проявів у дітей молодшого шкільного віку (Маляр O.I., 2017).

Соціально-психологічний тренінг передбачає п’ять занять, тривалістю 1-2 години, які проводяться раз на тиждень. Кількість учасників тренінгу - від 10 до 20 осіб. Комплекс вправ для батьків і вчителів був підібраний 3 психологопедагогічної літератури. Структура усіх занять тренінгу є наступною: привітання (1 вправа), що забезпечує позитивну атмосферу у групі, основна частина складається 33 - 4 вправ, спрямованих на формування у батьків та вчителів позитивного ставлення до емоційних проявів та особливостей соціальної поведінки у дітей молодшого шкільного віку. Окрім того, основна частина розрахована на вміння регулювати та звільнятися від негативних емоцій у житті. Інші вправи використовувалися для розвитку позитивного спілкування дорослих 3 дитиною та з оточуючими. У заключній частині використовувалися вправи на усвідомлення дорослим емоційного благополуччя дитини, як надзвичайно важливим джерелом духовного і морального розвитку дитини, що є основою розуміння, прийняття, визнання у суспільстві. Структура тренінгових занять представлена у таблиці1.

Соціально-психологічний тренінг може проводити один ведучий, але бажано, щоб було двоє. Це може бути психолог, який має уявлення про групову динаміку, знання вікової та соціальної психології, а другий ведучий - соціальний працівник, який не лише допомагає в проведенні тренінгу, а й спостерігає за проявами комунікації кожного учасника, які дають можливість спрогнозувати подальшу взаємодію та спілкування 3 дитиною. Також в процесі тренінгу учасники проявляють ті риси характеру, які вони не демонструють під час спілкування 3 соціальним працівником. Учасники групи після тренінгу 3 соціальним працівником або психологом краще пізнають один одного, розуміють особливості розвитку дитини i, як наслідок, можуть встановлюватися позитивні стосунки як 3 дитиною, так із соціальним працівником. 
Таблицяя 1.

Структура соціально-психологічного тренінгу: «Формування позитивних дитячо-батьківських стосунків та емоційна взаємодія вчителя 3 дитиною молодшого шкільного віку»

\begin{tabular}{|c|c|c|c|}
\hline $\begin{array}{c}\text { № } \\
\text { II/II }\end{array}$ & Тема заняття & Зміст заняття & $\begin{array}{c}\text { Тривалість, } \\
\text { год. }\end{array}$ \\
\hline 1 & $\begin{array}{l}\text { «Я, дитина та } \\
\text { емоції» }\end{array}$ & $\begin{array}{l}\text { Вправа «Це моя дитина», } \\
\text { Вправа «Зчитування емоції», Інформаційне } \\
\text { повідомлення: «Особливості емоційної } \\
\text { сфери дитини», Групова дискусія «Емоції } \\
\text { дитини», Вправа «П'ять добрих слів». }\end{array}$ & 1 \\
\hline 2 & $\begin{array}{l}\text { «Калейдоскоп } \\
\text { дитячих } \\
\text { емоційних } \\
\text { проявів» }\end{array}$ & $\begin{array}{l}\text { Вправа «Вітаю Вас», Вправа «Лист», Міні } \\
\text { лекція: «Негативні емоційні прояви } \\
\text { молодших школярів та їх причини», } \\
\text { Вправа «Емоційна реакція дитини», } \\
\text { Вправа «Усмішка». }\end{array}$ & 2 \\
\hline 3 & $\begin{array}{l}\text { « Мої правила - } \\
\text { емоції } \\
\text { дитини» }\end{array}$ & $\begin{array}{l}\text { Вправа «Риси моєї дитини», } \\
\text { Вправа «Екзамен для батьків», } \\
\text { Вправа «Валіза емоцій», } \\
\text { Вправа «Карусель», Вправа «Чотири зони } \\
\text { Гіппенрейтер», Вправа «Яблучко від } \\
\text { яблуньки», Вправа «Очищення від тривог» }\end{array}$ & 2 \\
\hline 4 & \begin{tabular}{l|} 
«Підвищення \\
психологічної \\
компетентності \\
вчителя \\
проблеми \\
розвитку \\
емоційної сфери \\
молодших \\
школярів»
\end{tabular} & $\begin{array}{l}\text { Вправа «Назад у дитинство», } \\
\text { Вправа «Скарбничка правил», } \\
\text { Вправа «Стінка», } \\
\text { Інформаційне повідомлення: «Особливості } \\
\text { емоційної сфери дитини», } \\
\text { Вправа «Емоція», } \\
\text { Вправа «Зрозумій іншого», } \\
\text { Вправа «Емоційний ланцюжок» }\end{array}$ & 2 \\
\hline 5 & $\begin{array}{l}\text { «Позитивні } \\
\text { стосунки вчителя } \\
3 \text { дитиною» }\end{array}$ & $\begin{array}{l}\text { Вправа «Риси дитини», Міні лекція: } \\
\text { «Негативні емоційні прояви молодших } \\
\text { школярів та їх причини», } \\
\text { Вправа «Оцінка дій дітей», } \\
\text { Вправа «Фасилітатор», } \\
\text { Вправа «Учитель -учень», } \\
\text { Вправа «Долонька добрих слів» }\end{array}$ & 2 \\
\hline
\end{tabular}


На кожному занятті використовували різні дидактичні прийомів інформаційні повідомлення, дискусії, різні види вправ, рольові ігри, аналіз складних ситуацій та інше. Інформаційне повідомлення - інформація, яка застосовується фахівцем (ведучим) як засіб подачі нового матеріалу для навчання учасників; дискусія - це вербальний обмін знаннями, ідеями чи думками між тренером та учасниками групи. Використання у нашому соціальнопсихологічному тренінгу, дискусії передбачає певну послідовність, тобто обмежувалися одним або двома питаннями під час або після завершення вправ і вони стосувалися тематики занять та емоційних переживань учасників групи. Також важливим елементом дискусії була демонстрація власних поглядів на те чи інше питання. Рольова гра дозволяє батькам та вчителям приміряти певні ролі та відчути деякі емоційні стани дитини та інших, що дає можливість краще зрозуміти особливості емоційної поведінки дитини і обрати ефективні способи спілкування та виховання. Під час тренінгових занять проводилися вправи на аналіз складних ситуацій, які виникають у взаємдії дорослого 3 дитиною, що дозволили учасникам усвідомити свою стереотипність, ригідність мислення, неадекватні настановлення до виховання дитини та розширити свої знання та соціальну компетентність щодо важливості позитивних дитячо-батьківських стосунків та взаємодії педагога з дітьми молодшого шкільного віку. Дані прийоми створюють позитивну та довірливу атмосферу, в якій учасники змогли поділитися власним життєвим досвідом, навчитися усвідомлювати проблеми дітей i знаходити способи їх вирішення.

Отже, розроблений нами соціально-психологічний тренінг допомагає дорослим, особливо батькам та вчителям, налагодити ефективне спілкування 3 дитиною молодшого шкільного віку, сформувати сучасні прийоми використання у вихованні емоційної сфери та соціальної поведінки підростаючої особистості та забезпечити комфортне перебування дитини у сім’ї та освітньому закладі.

\section{Висновки}

Успішність роботи соціального працівника з батьками та вчителями учнів молодших класів залежить від вибору форм та методів роботи. Практика доводить, що найбільш ефективним $є$ поєднання індивідуальних та групових форм роботи. Таким чином, проведений соціально-психологічний тренінг 3 формування позитивних дитячо-батьківських стосунків та емоційної взаємодії вчителя 3 дитиною молодшого шкільного віку надають можливість дорослим розширити свої знання про вікові особливості дитини та взаємодії з нею, ступінь iii благополуччя, про зв'язки між дорослими атитюдами та особистісними, комунікативними особливостями, а також особливостями поведінки та емоційновольової сфери молодших школярів, що формуються, розвиваються у межах 
даного вікового періоду. Використовуючи соціально-психологічний тренінг 3 батьками та вчителями соціальний працівник допомагає дорослим подолати труднощі у спілкуванні з дитиною, стати більш гнучкими в процесі їх взаємодії та сформувати навички успішного життя не тільки у дитини, а й у батьків та вчителів. Отже, соціально-психологічний тренінг з дорослими здатний розширити уявлення про спілкування з родичами та іншими людьми, про свої вміння і знання у різних сферах суспільного життя.

\section{Література}

Жуков, Ю. М. (1990). Диагностика и развитие компетентности в общении. Москва: МГУ. 104 с.

Ковалев, Г. А. (1998). Основные направления использования методов активного социального обучения в странах Запада. Психологический журнал. Т. 2, № 1. C. $127-133$.

Маляр, О. І. (2017). Розвиток довільності емоційної регуляції молодших школярів: корекційно-розвивальна програма: навчально-методичний посібник. Вінниця: ТОВ «Нілан-ЛТД».126 с.

Практикум по СПТ. / под ред. Парыгина, Б. Д. (2000). Санкт-Петербург : издательство Михайлова В. А. 352 с.

Туріщева, Л. В. (2007). Робота шкільного психолога з батьками. Навчальнометодичний посібник для вчителя. Харків. 256 с.

Федорчук, В. М. (2014). Тренінг особистісного зростання : навчальнометодичний посібник. Київ: «Центр учбової літератури». 250 с.

Шапар, В. Б. (2005). Сучасний тлумачний психологічний словник. Харків: Прапор. 640 с.

Шаргородська, С. (2007). Насилля в сім’ї: види, наслідки, шляхи подолання. Журнал Соціальний педагог. № 2(2). С. 14-16.

Masten, A. S. (2001). Ordinary magic: Resilience processes in development. American Psychologist. V. 56. P. 227-38.

Masten, A. S. (2007). Obradovic J. Disaster preparation and recovery: lessons from research on resilience in human development. Ecology and Society. URL: http://www.ecologyandsociety.org/vol13/iss1/art9/. 


\title{
SOCIO-PSYCHOLOGICAL TRAINING FOR THE FORMATION OF PARENT-CHILD RELATIONSHIPS AND THE EMOTIONAL INTERACTION OF A TEACHER WITH A CHILD IN THE CONTEXT OF THE WORK OF A SOCIAL WORKER
}

\author{
Olena Maliar, PhD., Senior Lecturer Department of Psychological-Pedagogical \\ Education and Social Sciences, CHEI «Vinnytsia Academy of Continuing Education», \\ Vinnytsia,Ukraine, malayryk@gmail.com
}

ABSTRACT. The article deals with socio-psychological training as one of the most effective and perspective directions of work of a social worker with a family. This training helps to solve a wide range of tasks, primarily related to communication in the family - the focus on correction and development of the system of relations of personality - competence in communicating with the child. In the context of the study, the essence of the concept of training (socio-psychological training) in the work of a social worker was disclosed.

There is described a training for parents and teachers about understanding the emotional development of the child and promoting of positive communication. The following methods were used: analysis, generalization of scientific literature on the use of social-psychological training by a social worker in working with family and teachers. The stages of preparation of parents and teachers in participation in social psychological training, which provide positive perception of training sessions with them, are presented. The author describes the structure of the author's social and psychological training on the formation of positive child-parent relationships and the emotional interaction of a teacher with a child of junior school age, which consists of five workshops.

It is concluded that the use of social-psychological training with the family in the work of a social worker provides positive perception of parents and teachers of the peculiarities of the social and psychological development of the child and the formation of tolerant communication with others in the adult.

Keywords: training; socio-psychological training; social worker; parents; teachers; pupil of junior school age.

\section{References}

Fedorchuk, V. M. (2014). Training of personal growth : tutorial manual. Kyiv: "Center for Uchebovoy Literature". 250 p. [In Ukrainian]. 
Kovalev, G. A. (1998). The main directions of the use of methods of active social education in Western countries. Psychological Journal. Issue 2 (1). P. 127-133 [In Russian].

Maliar, O. I. (2017). Development of arbitrariness of emotional regulation of junior schoolchildren: correctional-developmental program: educational and methodical manual. Vinnytsya: LLC "Nilan-LTD". 126 [In Ukrainian].

Masten, A. S. (2001). Ordinary magic: Resilience processes in development. American Psychologist. V. 56. P. 227-38.

Masten, A. S. (2007). Obradovic J. Disaster preparation and recovery: lessons from research on resilience in human development. Ecology and Society. URL: http://www.ecologyandsociety.org/vol13/iss 1/art9/.

Shapar, V. B. (2005). Modern interpretive psychological dictionary. Kharkov: Flag. 640 p. [In Ukrainian].

Shargorodskaya, S. (2007). Violence in the family: types, consequences, ways to overcome. Journal of Social Pedagogy. No. 2 (2). P. 14-16 [In Ukrainian].

Turyshcheva, L. V. (2007). Work of a school psychologist with parents. Teaching and methodological manual for a teacher. Kharkiv. 256 p. [In Ukrainian].

Workshop on SPT. ed. Parygina, B. D. (2000). St. Petersburg publishing house Mikhailov V. A. 352 p. [In Russian].

Zhukov, Yu. M. (1990). Diagnosis and development of competence in communication. Moscow : VGU. 104 p. [In Russian]. 